\title{
NYÍLVESSZŐK HAJLÍTÓ VIZSGÁLATA
}

\section{BENDING-TESTING OF ARROWS}

\author{
Pécsi Levente ${ }^{1}$, Pásztor Judit ${ }^{2}$, Kakucs András ${ }^{3}$ \\ ${ }^{1}$ VIVACOMSrl., Románia, Marosvásárhely, Jeddi út 79/A szám, \\ pecsi_levente@yahoo.com \\ ${ }^{2}$ Sapientia EMTE, Marosvásárhelyi Kar, 540485, Románia, Marosvásárhely, \\ Şoseaua Sighişoarei 1C., Tel.: +40 265208 170, Fax: +4026520621, \\ pjudit@ms.sapientia.ro \\ ${ }^{3}$ Sapientia EMTE, Marosvásárhelyi Kar, 540485, Románia, Marosvásárhely, \\ Şoseaua Sighişoarei 1C., Tel.: +40 265208 170, Fax: +4026520621, \\ kakucs2@ms.sapientia.ro
}

\begin{abstract}
The archery is at the same time an art form, a tradition, a style of martial arts and a competitive sport. Making up the equipment are the bow and arrows. The arrow deflection is a very important characteristic, which has a decisive influence on how and if the arrow reaches the target. This has a tremendous impact on the performance of the archer in both competition and archery demonstrations. The quantification and measurement of arrow deflection is equally important to both manufacturers and archers. The deflection is affected by the arrow's static bending. In this paper the bend of the arrow shall be determined.
\end{abstract}

Keywords: bow, arrow, bend, spine.

\section{Összefoglalás}

Az íjászat müvészet, harcművészet, hagyományőrzés és sport is egyben. Kellékei, az íj és a nyílvesszők igényesen kialakított eszközök, amelyek a történelem során erőteljes átalakuláson mentek keresztül. A nyílvessző kihajlása nagyon fontos jellemző. Ez döntő módon befolyásolja a vessző célba érését. Ez bemutatókon, versenyeken elvárandó teljesítés. A kihajlás számszerüsítése és mérése a gyártók és felhasználók számára egyformán lényeges. A kihajlást a vesszőlehajlás befolyásolja. A dolgozatban a nyílvessző lehajlása határozódik meg.

Kulcsszavak: ijj, nyílvesszö, lehajlás, spine.

\section{Bevezetés az íjászat elméletébe}

Az íjászat a nyílvesszők íjjal való kilövését jelentő tevékenység. Az íj és a nyílvessző a pattintott kőkorszakban jelent meg. Kezdetben botíjak voltak, amelyek alig különböztek a mai angol hosszúíjtól. A vadászatban és a hadviselésben bírt nagy jelentőséggel, számos népnek segített vilá- got hódítani, napjainkban sportként él tovább.

Az íjászat alapkellékei az íj és a nyílvesszők.

Az íj egy ívelt formájú, rugalmas tárgy. Erős anyagból készült, idegnek nevezett, zsinór egyesíti az ív két végét. Az ideg megfeszítése hajlítást eredményez az ív karnak nevezett részében. Nyílvesszőnek 
nevezett lövedéket lö, mely egy aerodinamikus test.

Az történelem során az íjak hosszúíjakra és reflexíjakra alakultak. A technológiai haladás a következő típusokat eredményezte: hagyományos íj (történelmi íjak); vadászreflex íj és csupasz íj; olimpiai (sport íj); csigás íj; nyílpuska (számszeríj). Az íj általános felépítése az 1. ábrán látható.

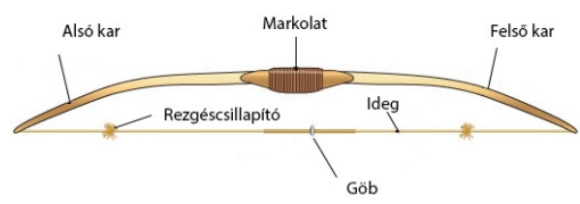

1. ábra. Hosszúíj felépítése [3]

A nyílvessző részei az 2. ábrán láthatóak.

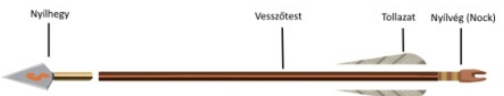

2. ábra. Nyílvesszö felépitése [3]

A nyílvessző vesszőtestei fából, üvegszálból, alumíniumból, szénszálból- karbonszálból, vegyes felépítéssel készülnek. A vesszők osztályba sorolása az átmérő, keménység és tömegük alapján történik. A hagyományos harci eszközöket, amely népcsoportonként változó formát és méretet mutatnak, a sportíjászat egybefogja, részben szabványosítja.

\section{2. Íjazás elmélete}

Az íj tulajdonképpen egy egyszerü gép. Erős anyagból készült, idegnek nevezett zsinór egyesíti az íj két végét. Az ideg megfeszítése által hajlítást eredményez a karnak nevezett részen. Amikor felszabadul az ideg, az a lehető leggyorsabban igyekszik visszanyerni nyugalmi helyzetét, ezáltal a rá megfelelö szögben helyezett nyílvesszőt maga előtt taszítja, átadva az íj megfeszített karjainak potenciális energiájának egy részét a vesszőnek, megnövelve annak sebességét. A vessző a szabad-dobás elvét követve halad a cél fele.

A célba érést számos tényező befolyásolja, az íj anyaga, kialakítása, a húzóerő, a húzáshossz, az előfeszítettség, a felajzás magassága. Legfontosabb a nyílvessző profilja, hajlási tényezője, tömege. De fontos tényező maga az íjász és a környezet is.

Az íjász sikere az adott helyzethez alkalmas eszközpárosításban rejlik. Ezért nagyon fontos ismerni a nyílvesszőt és az íjat.

Az nyílvesszőválasztás nagyon fontos jellemzője a spine, a nyílvessző lehajlásával számszerüsített minősítés értéke. A lehajlás hajlított rúd tengelyének elmozdulása a tengelyre merőleges irányban [2].A vessző lehajlása, a statikus spine, fontos információ, hiszen általa jobban megbecsülhető a lövéskor keletkező kihajlás, a dinamikus spine. A kihajlás a nyomott rudak stabilitásvesztésének a jelensége, amelynek során a rúd a túl nagy tengelyirányú nyomóerő hatására meghajlik [2]. A kihajlás a vessző megfelelő pályára állását biztosítja, 3. ábra. Erre a jellemzőre közvetve a vessző merevségéből, keménységéből lehet következtetni.

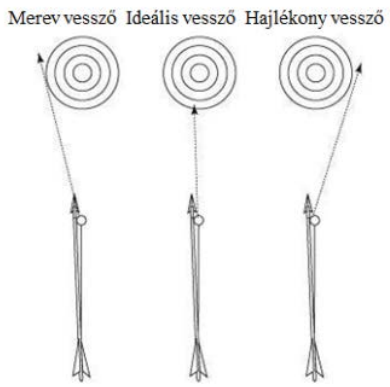

3. ábra. Vesszökeménység hatása [3]

A vessző merevségének ismerete segíti az íjászt az eszközpárosításban. A nyílveszsző keménységét lehajlás vizsgálattal állapítják meg, ez a hajlítással szembeni merevséget jelenti. Mérőeszköze, az íjászszlengben használt, spine-teszter. 


\section{Mérés és adatfeldolgozás}

A mérés érdekében megvalósított berendezés a 4. ábrán látható. Részei egy tartóállvány, a vesszőközepet terhelő tömeg és a lehajlást mérő subler.

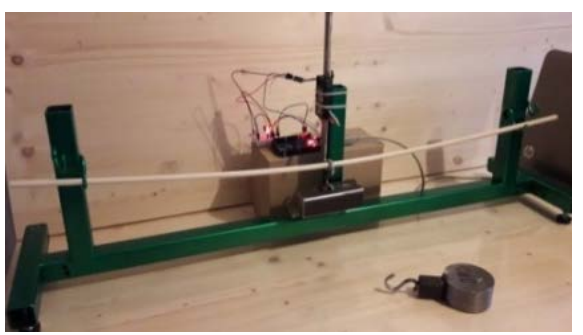

4. ábra. Spine-teszter

A mérés módszere: a vesszőt két pontban alátámasztjuk és az alátámasztási pontok közötti távolság felénél a tengelyére merőlegesen súlyokkal statikusan terheljük. Az alátámasztási pontok közötti távolság és a használt tömeg, amellyel a vesszőtest közepét terheljük, a nyílvessző anyagától függ. Mérjük a lehajlás nagyságát terhelt és a nem terhelt állapotok között, és különbséget számolunk, 5. ábra.

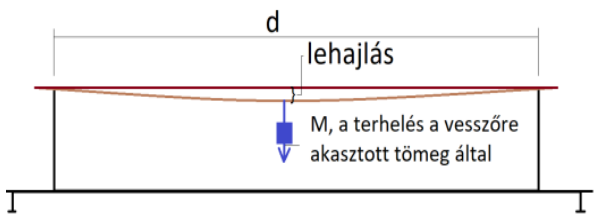

5. ábra. Mérés módszere

Favesszők esetében a lehajlás értéket úgy határozzuk meg, az AMO szabvány, Archery Manufacturers Organization szerint a vesszőt egymástól $\mathrm{d}_{1}=26$ colra levő pontban alátámasztjuk és közepét $\mathrm{M}_{1}=2$ fonttal, 907,2 gramm-al terheljük, 5. ábra. A vessző közepénél mért eredeti helyzet és a terhelt helyzet közötti távolság határozza meg a lehajlás értékét, melyet colba fejezünk ki, majd az AMO szabvány alapján ezt a spine-nak feleltetjük meg. A lehajlás és a spine megfeleltetése az AMO szabvány felhasználásával a 6. ábrán látható. Ez a szabvány a favesszőkre érvényes.

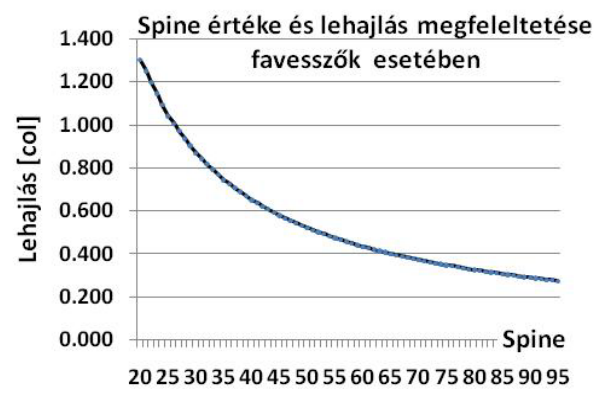

6. ábra. Favesszők osztályba sorolása

Karbon és alu-karbon anyagú vesszötestek mérésénél a mérés módszere változik, $\mathrm{d}_{2}=28$ col, távolságra támasztjuk alá a veszszőt és 1.94 fontnyi tömeget, azaz $\mathrm{M}_{2}=880$ grammot használunk terheléskor. Ez esetben a vesszőtest közepén mért két végállás közti eltérést megszorozzuk 1000-rel, a kapott értéket kerekítjük és a spine-nak feleltjük meg a 7. ábra alapján.

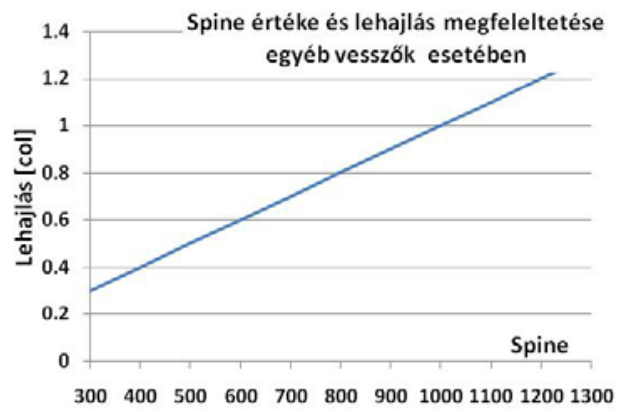

7. ábra. Nem fából készült vesszök osztályba sorolása

A lehajlási tényező fontosságára már a múlt század közepén felfigyeltek az amerikai nyílvessző készítők, gyártók és rendszerezni próbálták azok minősítését, jelölését. A létrehozott szabvány első sorban a fából készült nyílvesszők bemérésére szolgált, mely a merevségüket jelentette és több diszkrét értékből egy nemlineáris összefüg- 
gés íródik le, 6. ábra. Minél merevebb a vesszőtest annál nagyobb a lehajlási tényezője. Ez megtévesztőnek bizonyult a hamarosan megjelenő modern anyagokból készült nyilak esetében, így azokat már intervallumba sorolták és a vessző hajlékonyságát mérték. Az egyik a másik inverze, tehát ez esetben, az előbbiekkel ellentétben, minél merevebb a vesszőtest, annál kisebb a lehajlási tényezője, 7.ábra. Mindkét esetben, fa- illetve modern anyagból készült vesszők esetén is, az univerzálisan elfogadott és használt szakszó, az angol "spine” kifejezés jelöli a vesszőtestek merevségét. Aki jártas mindkét mérési szabványban az megérti a spine szó jelentését a kontextusból, viszont a laikusok számára nagyon megtévesztő, mert jelenthet merevséget, de hajlékonyságot is.

Méréssorozatunkban két sorozat fa- és két sorozat karbonvesszöt mértünk meg, minden vesszőt háromszor, 45-onként elfordítva. Az adatokat és a számításokat táblázatba rögzítettük. A táblázatok terjedelme miatt, csak egy részletet ismertetünk, 1. táblázat.

1. táblázat. Karbon nyílvesszők mért lehajlása és a spine érték megfeleltetése

\begin{tabular}{|c|c|c|c|c|c|c|c|c|c|c|c|c|c|}
\hline \multicolumn{14}{|c|}{ Karbon nyílvesszők } \\
\hline Karbon & \multicolumn{3}{|c|}{ Kihajlás [col] } & \multicolumn{3}{|c|}{ Kihajlás [mm] } & \multicolumn{2}{|c|}{ Átlag kihajlás } & \multicolumn{2}{|c|}{ Min. kihajlás } & \multirow[b]{2}{*}{ Spine érték } & \multicolumn{2}{|c|}{ Tömeg } \\
\hline Vesszőszám & 1 & 2 & 3 & 1 & 2 & 3 & col & $\mathrm{mm}$ & col & $\mathrm{mm}$ & & grain & gramm \\
\hline 1 & 0.568 & 0.576 & 0.560 & 14.427 & 14.630 & 14.224 & 0.568 & 14.427 & 0.560 & 14.224 & 560 & 391.800 & 25.388 \\
\hline 2 & 0.569 & 0.575 & 0.579 & 14.453 & 14.605 & 14.707 & 0.574 & 14.588 & 0.569 & 14.453 & 569 & 386.600 & 25.051 \\
\hline 3 & 0.570 & 0.574 & 0.578 & 14.478 & 14.580 & 14.681 & 0.574 & 14.580 & 0.570 & 14.478 & 570 & 390.200 & 25.285 \\
\hline 4 & 0.584 & 0.595 & 0.595 & 14.834 & 15.113 & 15.113 & 0.591 & 15.020 & 0.584 & 14.834 & 584 & 390.000 & 25.272 \\
\hline 5 & 0.588 & 0.602 & 0.591 & 14.935 & 15.291 & 15.011 & 0.594 & 15.079 & 0.588 & 14.935 & 588 & 392.400 & 25.427 \\
\hline 6 & 0.578 & 0.596 & 0.597 & 14.681 & 15.138 & 15.164 & 0.590 & 14.994 & 0.578 & 14.681 & 578 & 395.000 & 25.596 \\
\hline 7 & 0.568 & 0.587 & 0.588 & 14.427 & 14.910 & 14.935 & 0.581 & 14.757 & 0.568 & 14.427 & 568 & 392.000 & 25.401 \\
\hline 8 & 0.672 & 0.710 & 0.716 & 17.069 & 18.034 & 18.186 & 0.699 & 17.763 & 0.672 & 17.069 & 672 & 317.000 & 20.541 \\
\hline 9 & 0.687 & 0.692 & 0.692 & 17.450 & 17.577 & 17.577 & 0.690 & 17.534 & 0.687 & 17.450 & 687 & 316.400 & 20.502 \\
\hline 10 & 0.708 & 0.716 & 0.730 & 17.983 & 18.186 & 18.542 & 0.718 & 18.237 & 0.708 & 17.983 & 708 & 318.700 & 20.651 \\
\hline 11 & 0.713 & 0.718 & 0.719 & 18.110 & 18.237 & 18.263 & 0.717 & 18.203 & 0.713 & 18.110 & 713 & 311.700 & 20.198 \\
\hline 12 & 0.710 & 0.718 & 0.722 & 18.034 & 18.237 & 18.339 & 0.717 & 18.203 & 0.710 & 18.034 & 710 & 310.400 & 20.114 \\
\hline 13 & 0.693 & 0.707 & 0.724 & 17.602 & 17.958 & 18.390 & 0.708 & 17.983 & 0.693 & 17.602 & 693 & 317.300 & 20.561 \\
\hline
\end{tabular}

Az adatok kiértékelése során meghatároztuk egy-egy a nyílvessző sorozat lehajlásának konfidencia intervallumát 95\%-os valószínüséggel [1]. Az adatokat a 2. táblázat jeleníti meg.

2. táblázat. A nyilvesszök kihajlásának becslése fa és karbon vesszökre

\begin{tabular}{|c|c|c|c|c|c|c|}
\hline Vesszö & \multirow{2}{*}{$\begin{array}{c}\text { Mnérések } \\
\text { anyaga }\end{array}$} & Tapasztalati & \multirow{2}{*}{ toos } & \multicolumn{2}{|c|}{ Becsült érték } \\
\cline { 5 - 7 } & & átlaga [col] & szórás & & Alsó határa & Felső határa \\
\hline \multirow{2}{*}{ Fa } & 12 & 0.990 & 0.064 & 2.201 & 0.950 & 1.031 \\
\cline { 5 - 7 } & 14 & 0.547 & 0.018 & 2.160 & 0.537 & 0.558 \\
\hline \multirow{2}{*}{ Karbon } & 7 & 0.582 & 0.009 & 2.447 & 0.573 & 0.590 \\
\cline { 5 - 7 } & 6 & 0.708 & 0.010 & 2.571 & 0.697 & 0.719 \\
\hline
\end{tabular}

Az általunk meghatározott lehajlások három sorozat esetén megegyeztek a gyártó által megadott értékekkel.

\section{Következtetések}

A nyílvessző biztos, zavartalan, pontos célba érése érdekében a lehajlása a lehető legkedvezőbb kell, hogy legyen az adott felszereléshez, lövési technikához és környezeti körülményekhez. Tehát a spline-t célszerü meghatározni, hogy az íjász tudja megfelelően kiválasztani az eszközeit.

\section{Szakirodalmi hivatkozások}

[1] Kemény, S., Deák, A.: Kísérletek tervezése és értékelése. Müszaki Könyvkiadó, Budapest, 2000, p.26-54.

[2] Muttnyánszky, Á.: Szilárdságtan, Müszaki Kiadó, Budapest, 1981.

[3] http://preppergirluk.yolasite.com/resources/b ow_parts_longbow.jpg, (2017.05.05) 